\title{
Beneficial or harmful influence of phytosterols on human cells?
}

\author{
Blazej Rubis ${ }^{1}$, Anna Paszel ${ }^{1}$, Mariusz Kaczmarek ${ }^{2}$, Magdalena Rudzinska ${ }^{3}$, Henryk Jelen ${ }^{3}$ \\ and Maria Rybczynska ${ }^{1 *}$ \\ ${ }^{1}$ Department of Clinical Chemistry and Molecular Diagnostics, Poznan University of Medical Sciences, Przybyszewskiego 49 St, \\ 60-355 Poznan, Poland \\ ${ }^{2}$ Department of Clinical Immunology, Poznan University of Medical Sciences, Rokietnicka 5d St, 60-806 Poznan, Poland \\ ${ }^{3}$ Department of Food Science and Nutrition, The August Cieszkowski Agricultural University of Poznan, Wojska Polskiego 31 St, \\ 60-624 Poznan, Poland
}

(Received 23 November 2007 - Revised 4 March 2008 - Accepted 7 March 2008 - First published online 29 April 2008)

So far, a protective influence of phytosterols on the human organism and atherogenesis has been suggested. Most studies have concentrated on the cytotoxic efficacy of phytosterols on cancer cells. However, there are only a few reports showing their influence on normal cells. The aim of the present study was to determine whether dietary plant sterols and their thermal processing products could influence the viability of normal, abdominal endothelial cells that play a crucial role in atherogenesis. Thus, we studied the effect of rapeseed oil-extract components, $\beta$-sitosterol, cholesterol and their epoxy-derivatives, $5 \alpha, 6 \alpha$-epoxy- $\beta$-sitosterol and $5 \alpha, 6 \alpha$-epoxycholesterol, on the proliferation and viability of human abdominal aorta endothelial cells HAAE- 2 in vitro. We showed strong cytotoxic properties of $\beta$-sitosterol in HAAE- 2 cells (half maximal inhibitory concentration $\left.\left(\mathrm{IC}_{50}\right)=1.99(\mathrm{SEM} 0.56) \mu \mathrm{M}\right)$ and, interestingly, a weaker cytotoxic effect of $5 \alpha, 6 \alpha$-epoxy- $\beta$-sitosterol $\left(\mathrm{IC}_{50}>200 \mu \mathrm{M}\right)$. Moreover, we observed a significantly stronger cytotoxic activity of $\beta$-sitosterol than cholesterol $\left(\mathrm{IC}_{50}=8.99(\mathrm{SEM} 2.74) \mu \mathrm{M}\right)$. We also revealed that $\beta$-sitosterol as well as cholesterol caused apoptosis, inducing caspase-3 activity in the cells (60\% increase compared with control cells) that corresponded to the DNA fragmentation analysis in a terminal uridine deoxynucleotidyl transferase-mediated deoxyuridine triphosphate nick-end labelling (TUNEL) study. Although absorption of plant sterols is low compared with cholesterol, they can still influence other physiological functions. Since they effectively reduce serum LDL-cholesterol and atherosclerotic risk but also decrease the viability of cancer cells as well as normal cells in a time- and dose-dependent manner in vitro, their influence on other metabolic processes remains to be elucidated.

Endothelial cells: HAAE-2: $\beta$-Sitosterol: Apoptosis: Atherosclerosis

Epidemiological studies indicate that a diet rich in plant foods contributes to a decreased risk of cardiovascular disorders and it is also suggested that plant sterols, especially sitosterol, might have protective properties against CVD as well as against different types of cancer ${ }^{(1)}$. The anti-atherosclerotic action of phytosterols has been shown in many studies and it has been reported that phytosterols ( $\beta$-sitosterol) inhibit the growth and development of tumours ${ }^{(2,3)}$. One of the postulated and already well-known mechanisms of phytosterol action in cancer cells is activation of the sphingomyelin cycle, thus leading to cell apoptosis. Other studies have shown that phytosterols might mediate apoptosis initiation through caspase activation $^{(1)}$. They were also shown to decrease the metastasis process; however, that phytosterol activity was postulated to result from incorporation of sitosterol in the cell-membrane structure resulting in a decreased cholesterol level and consequently leading to cell-cycle arrest in the $\mathrm{G}_{2} / \mathrm{M}$ phase ${ }^{(3,4)}$. It was clearly shown that there are obvious correlations between individual cancer types and population, resulting from different cultural cooking traditions.
However, the mechanism of protective phytosterol action is not yet completely understood. It is supposed that the plant sterols might influence the composition of the cell membrane and its fluidity but they could also interact with the membrane enzymes, intracellular signal-transduction pathways, apoptosis and immunological functions. Moreover, oestrogenic activity of phytosterols is postulated ${ }^{(5)}$. In many studies an anti-atherogenic action of phytosterols has been shown and been explained by a decreased number of foam cells in the plaque. Interestingly, no cytotoxic activity of phytosterols has been shown considering normal, non-cancer Chang Liver line cells; however, it has been reported that phytosterols and stanols effectively lower the serum level of LDL and thus the atherosclerosis risk ${ }^{(6)}$. Clinical data have shown that a phytosterol-rich diet, consisting of vegetables, fruits and vitamins $\mathrm{C}$ and $\mathrm{E}$, results in reduced breast cancer morbidity ${ }^{(7)}$.

Phytosterols are known to have protective properties in endothelial cells while their oxy-derivatives are supposed to harm the cells and generate free radical reactive oxygen

Abbreviations: $\mathrm{IC}_{50}$, half maximal inhibitory concentration; MTT, 1-(4,5-dimethylthiazol-2-yl)-3,5-diphenylformazan; SMC, smooth muscle cell; TUNEL, terminal uridine deoxynucleotidyl transferase-mediated deoxyuridine triphosphate nick-end labelling.

* Corresponding author: Dr Maria Rybczynska, fax +48 6186914 27, email mrybczyn@ump.edu.pl 
species $^{(8)}$. However, it is postulated that the precursor compounds, phytosterols, might also generate reactive oxygen species during their cell metabolism and thus provoke disruption of cell metabolism. Plant sterols and stanols, being more hydrophobic than cholesterol, may displace cholesterol from mixed micelles, and thus reduce the micellar cholesterol concentrations and consequently lower cholesterol absorption. Finally, plant sterols and stanols, effectively lowering serum LDL-cholesterol levels, may play an important role in atherosclerotic lesion development and plaque regression. However, their pro-apoptotic influence on endothelial cells must also be considered, especially in the context of phytosterol supplementation of hypercholesterolaemic subjects.

The aim of the study was to evaluate and compare the influence of cholesterol, phytosterols and oxysterols on human abdominal aorta endothelial cells HAAE-2 in vitro. We decided to estimate the effect of sterols on normal cells and to study the potential adverse effects of treatment for cancer or hypercholesterolaemia prevention. Sitosterol oxidises to $7 \alpha-$ and $7 \beta$-hydroperoxysitosterol, which is reduced to $7 \alpha$-hydroxysitosterol and $7 \beta$-hydroxysitosterol; dehydration of hydroperoxysitosterol leads to the formation of 7-ketositosterol. Epoxidation of the double bond between the C5 and C6 atoms of sitosterol results in $5 \alpha, 6 \alpha-$ and $5 \beta, 6 \beta$-epoxysitosterol, which could be converted to sitostantriol. The association of high plant sterol levels in sitosterolaemic subjects and atherosclerosis is documented in the work of Salen et al. ${ }^{(9)}$. These authors confirmed the correlation between the plant sterols and atherosclerosis in an 18-yearold male with sitosterolaemia who died suddenly of an acute myocardial infarction. Their findings indicate that atherosclerosis occurs prematurely in sitosterolaemia and probably results from accelerated plasma sterol levels.

\section{Materials and methods}

\section{Reagents}

The 1-(4,5-dimethylthiazol-2-yl)-3,5- diphenylformazan (MTT) proliferation assay (Roche Diagnostics, Indianapolis, IN, USA), terminal uridine deoxynucleotidyl transferase-mediated deoxyuridine triphosphate nick-end labelling (TUNEL; Roche Diagnostics), the EnzChek ${ }^{\circledR}$ caspase-3 assay kit no. 2 - Z-DEVD-R110 substrate (Invitrogen, Carlsbad, CA, USA) and trypan blue (0.4\%; Sigma-Aldrich, St Louis, MO, USA) were used.

\section{Cell culture}

Human abdominal aorta endothelial cells, HAAE-2, were purchased from the American Type Culture Collection (ATCC no. CRL-2473; Manassas, VA, USA). Cells were cultured in standard conditions providing $100 \%$ humidity and $5 \%$ atmosphere of carbon dioxide at $37^{\circ} \mathrm{C}$. Ham's $\mathrm{F} 12 \mathrm{~K}$ medium containing $2 \mathrm{~mm}-\mathrm{L}$-glutamine, sodium bicarbonate $(1.5 \mathrm{~g} / \mathrm{l})$ (American Type Culture Collection) was supplemented with $10 \%$ fetal bovine serum, heparin $(0.1 \mathrm{mg} / \mathrm{ml})$, endothelial cell growth factor $(0.03 \mathrm{mg} / \mathrm{ml})$ and gentamycin $(100 \mu \mathrm{g} / \mathrm{ml})$ (all supplements from Sigma-Aldrich).

\section{Study compounds}

A $\beta$-sitosterol standard containing $13 \%$ of sitostanol (Research Plus, Inc., Bayonne, NJ, USA) diluted in acetone was used for oxidation experiments. For cytotoxicity assays, synthetic $\beta$-sitosterol from Sigma was used. Standards of $5 \alpha, 6 \alpha$-epoxysitosterol, cholesterol, $5 \alpha, 6 \alpha$-epoxycholesterol, $\beta$-epoxycholesterol and 19-hydroxycholesterol were obtained from Steraloids Inc. (Newport, RI, USA). The oil extract was an oxyphytosterol mixture (for content, see Table 1) obtained by the thermal processing and oxidation of $1 \mathrm{~g}$ crude rapeseed oil. Reagents used for phytosterol oxidation and for their analyses were purchased from Sigma-AldrichFluka (St Louis, MO, USA). For sample clean-up, SPE SepPak NH2 columns (Waters Corp., Milford, MA, USA) were used. TLC separation was performed on Silica gel 60 F254, $20 \times 20 \mathrm{~cm}, 0.25 \mathrm{~mm}$ (Merck, Whitehouse Station, NJ, USA).

\section{Identification and quantification of compounds}

For the identification of phytosterol oxidation products a Trace 2000 gas chromatograph coupled to a POLARIS Q mass spectrometer (Thermo-Finnigan, Austin, TX, USA) was used equipped with a $50 \mathrm{~m}$ DB-5 column $(50 \mathrm{~m} \times$ $0.25 \mathrm{~mm} \times 0.25 \mu \mathrm{m})$. The same column was used for the separation of phytosterol oxidation products by GC which was carried out on a Hewlett Packard HP 6890 gas chromatograph with a flame ionisation detector.

\section{Oxidation of $\beta$-sitosterol}

The standard of $\beta$-sitosterol was oxidised according to the method of Fieser \& Fieser ${ }^{(10)}$. First, $\beta$-sitosterol $(2.42 \mathrm{~g}$ ) was dissolved in $30 \mathrm{ml} \mathrm{CH}_{2} \mathrm{Cl}_{2}$ in a $100 \mathrm{~cm}^{3}$ round flask with a magnetic stirrer and kept at $25^{\circ} \mathrm{C}$. Then to the flask $1.23 \mathrm{~g}$

Table 1. Oxyphytosterol content in crude rapeseed oil after heating at $180^{\circ} \mathrm{C}$ for $3 \mathrm{~d}^{\star}$

(Mean values with their standard errors of three experiments)

\begin{tabular}{|c|c|c|}
\hline \multirow[b]{2}{*}{ Compound } & \multicolumn{2}{|c|}{ Oxyphytosterol content ( $\mu \mathrm{g} / \mathrm{g}$ oil) } \\
\hline & Mean & SEM \\
\hline $7 \alpha$-Hydroxycampesterol & 23.55 & $4 \cdot 72$ \\
\hline $7 \beta$-Hydroxycampesterol & $26 \cdot 75$ & 1.05 \\
\hline$\beta$-Epoxycampesterol & $27 \cdot 02$ & $1 \cdot 72$ \\
\hline$\alpha$-Epoxycampesterol & $20 \cdot 39$ & $1 \cdot 8$ \\
\hline Triol-campesterol & $7 \cdot 67$ & $1 \cdot 21$ \\
\hline 7-Ketocampesterol & $17 \cdot 66$ & $9 \cdot 24$ \\
\hline $7 \alpha$-Hydroxysitosterol & 43.28 & $4 \cdot 14$ \\
\hline $7 \beta$-Hydroxysitosterol & $156 \cdot 88$ & $8 \cdot 59$ \\
\hline$\beta$-Epoxysitosterol & $16 \cdot 33$ & 1.53 \\
\hline$\alpha$-Epoxysitosterol & $7 \cdot 63$ & $1 \cdot 24$ \\
\hline Triol-sitosterol & 4.96 & 1.59 \\
\hline 7-Ketositosterol & $33 \cdot 21$ & 0.51 \\
\hline $7 \alpha-$ Hydroxystigmasterol & $11 \cdot 82$ & 0.55 \\
\hline $7 \beta$-Hydroxystigmasterol & 2.65 & 0.04 \\
\hline$\beta$-Epoxystigmasterol & \multicolumn{2}{|c|}{ nd } \\
\hline$\alpha$-Epoxystigmasterol & \multicolumn{2}{|c|}{ nd } \\
\hline Triol-stigmasterol & \multicolumn{2}{|c|}{ nd } \\
\hline 7-Ketostigmasterol & \multicolumn{2}{|c|}{ nd } \\
\hline
\end{tabular}

nd, Not detected.

* The content of oxyphytosterols was measured as described in Materials and methods. 
$m$-chloroperbenzoic acid dissolved in $12 \mathrm{ml} \mathrm{CH}_{2} \mathrm{Cl}_{2}$ was added. The reaction was performed for $2 \mathrm{~h}$. The surplus of oxidising reagent was eliminated by the addition of $10 \%$ sodium sulfate. The mixture was transferred into a separatory funnel and washed twice with $5 \% \mathrm{NaHCO}_{3}(25 \mathrm{ml})$ to remove the $m$-chloroperbenzoic acid. Then the sample was washed twice with $25 \mathrm{ml}$ saturated $\mathrm{NaCl}$. The organic layer was then evaporated under a stream of $\mathrm{N}_{2}$ and dissolved in chloroform.

A sample of oxidised $\beta$-sitosterol was applied to the TLC silica gel plate. Epoxycholesterol was used as a reference compound. The plate was developed in ethyl ether-cyclohexane $(9: 1, \mathrm{v} / \mathrm{v})$, dried, and then the part containing standards was sprayed with a developing reagent (prepared by dissolving $1 \mathrm{~g}$ hydrated phosphomolibdenic acid, $1 \mathrm{~g}$ hydrated cerium sulfate and $5.4 \mathrm{ml}$ sulfuric acid in $100 \mathrm{ml}$ water). The sprayed plate was dried at $120^{\circ} \mathrm{C}$ for $15 \mathrm{~min}$. The zone corresponding to epoxysitosterol was scraped and eluted from the silica using a chloroform-methanol $(2: 1, v / v)$ mixture. Finally the solvent was evaporated and compounds identified using GC-MS (Fig. 1). The epoxysitosterol content in this fraction was estimated to be about $80 \%$.

\section{Preparation of oxyphytosterol fraction from heated} rapeseed oil

Crude rapeseed oil obtained from ZPT (Warsaw, Poland) was heated at $180^{\circ} \mathrm{C}$ for $8 \mathrm{~h}$ every day for $3 \mathrm{~d}$. The oxyphytosterol content was analysed according to the procedure described by Rudzińska et al. ${ }^{(11,12)}$. Briefly, $250 \mathrm{mg}$ rapeseed oil was transesterified with $10 \%$ sodium methanolate and extracted with chloroform. To isolate the oxyphytosterols the lipid mixture was fractionated by solid-phase extraction on $360 \mathrm{mg} \mathrm{NH} 2$ columns (Waters Corp., Milford, MA, USA). Isolated oxyphytosterol fractions were silylated with $75 \mu$ l Sylon ${ }^{\mathrm{TM}}$ HTP (Supelco, Bellefonte, PA, USA) for $4 \mathrm{~h}$ at room temperature and analysed by GC-MS and GC-flame ionisation detection. As an internal standard, 19-hydroxycholesterol was used. The quantitative results are presented in Table 1. For the cytotoxicity assay the fraction of oxyphytosterols was isolated from $1 \mathrm{ml}$ of heated crude rapeseed oil according to the same procedure. The sample after fractionation on Sep-Pak $\mathrm{NH} 2$ (Waters Corp.) was used for the analysis.

\section{Cytotoxicity assay: 1-(4,5-dimethylthiazol-2-yl) -3,5-diphenylformazan}

Cells (4000) were seeded for 24 and $72 \mathrm{~h}$ in Ham's F12K medium, as specified in the Cell culture section, on ninetysix-well titration plates in the presence of test substances dissolved in acetone. At time intervals, $0.5 \%$ MTT was added. After $16 \mathrm{~h}$ incubation the solubilisation solution was added $(10 \%$ SDS in $0.15 \mathrm{~mm}-\mathrm{HCl})$ in order to visualise the metabolised $\mathrm{MTT}^{(13)}$. Absorbance intensity was measured by a Labsystems Multiscan RC reader (Labsystems, Helsinki,

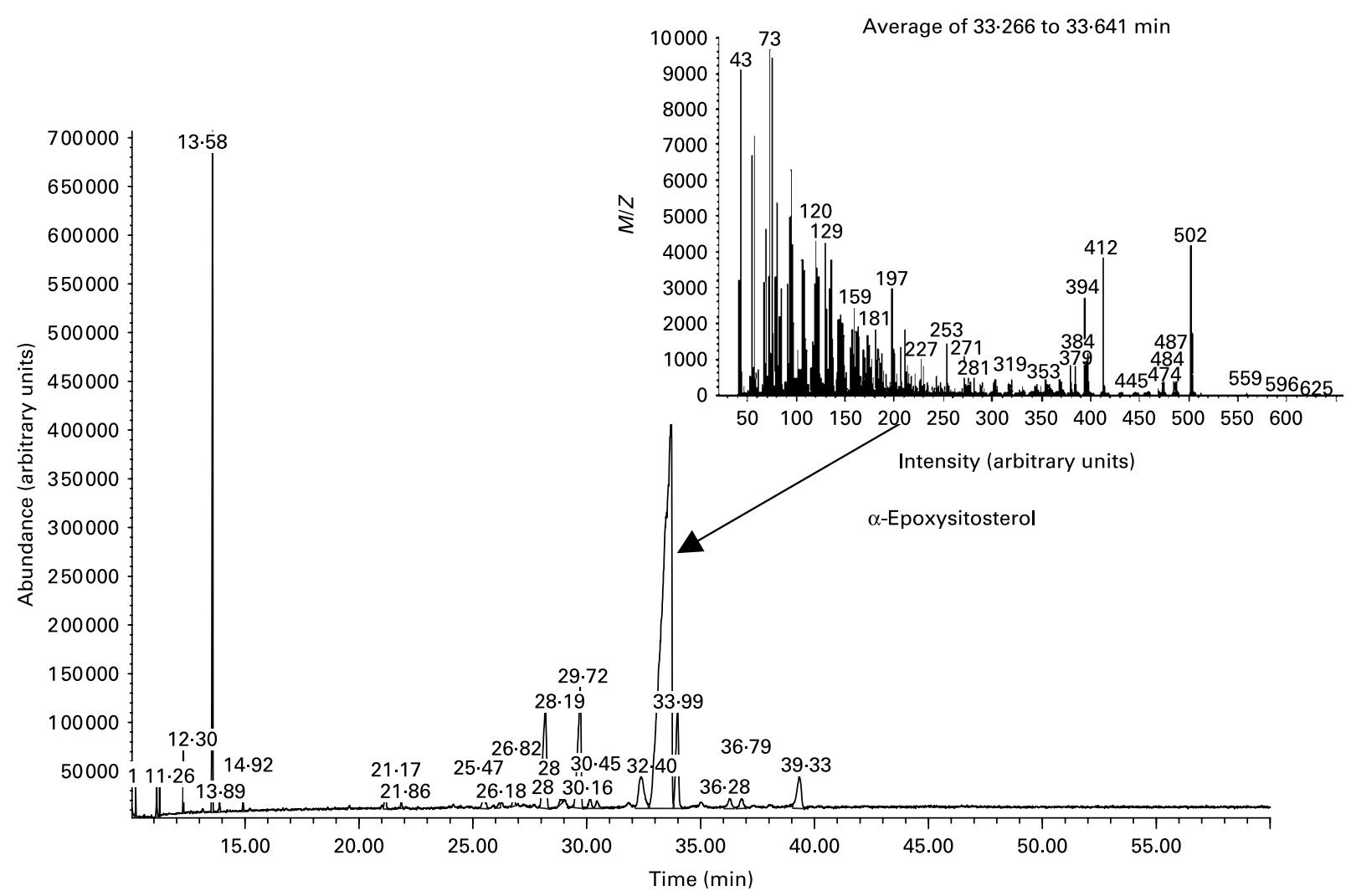

Fig. 1. Total ion chromatogram of TLC scraped fraction corresponding to epoxysitosterol, which was used subsequently for the cytotoxicity assays. Defined standard of $\beta$-sitosterol was oxidised according to the method of Fieser \& Fieser ${ }^{(10)}$. The sample was applied to the TLC silica gel plate and epoxycholesterol was used as a reference compound. The zone corresponding to epoxysitosterol was scraped and eluted from the silica using a chloroform-methanol (2:1, v/v) mixture. Finally the solvent was evaporated and compounds identified using GC-MS. 
Finland) at $\lambda=570$ and $690 \mathrm{~nm}$. Proliferation rate was expressed as the absorbance of a sample compared with control cells treated with acetone $(1 \%)$ and the half maximal inhibitory concentration $\left(\mathrm{IC}_{50}\right)$ values were calculated in CalcuSyn (BioSoft, Ferguson, MO, USA).

\section{Cell viability assay}

The viability of cells was evaluated after $24 \mathrm{~h}$ incubation in the presence of test substances. After treatment, all cells were stained with $0.4 \%$ trypan blue $(1: 1, \mathrm{v} / \mathrm{v})$ and counted in a haemocytometer with a Neubauer net. The number of cells with a functioning membrane was compared with the total cell number.

\section{Caspase-3 activity}

Caspase- 3 activity was assessed according to the manufacturer's instructions. Briefly, cells $\left(8 \times 10^{5}\right)$ were incubated with test substances for $24 \mathrm{~h}$, collected and lysed for $30 \mathrm{~min}$ at $4^{\circ} \mathrm{C}$. After centrifugation at $5000 \mathrm{rpm}$ for $5 \mathrm{~min}$ the supernatant fraction was collected, transferred onto a microplate and incubated with Z-DEVD-R110, caspase-3 substrate, for $30 \mathrm{~min}$, followed by fluorescence detection at $\lambda=496 / 520 \mathrm{~nm}$ (Delfia-Victor-2; Perkin Elmer, Waltham, MA, USA). The concentration of compounds was calculated according to the cytotoxic effect shown in the MTT test and it was half of the $\mathrm{IC}_{50}$ value for sterols and their oxy-derivatives. The concentration of oil extract was standardised against $\beta$-sitosterol and its epoxyderivative content. The final concentrations of those compounds in cells treated with oil extract was chosen to be close to the $\mathrm{IC}_{50}$ values, achieved in the MTT test.

\section{Terminal uridine deoxynucleotidyl transferase-mediated} deoxyuridine triphosphate nick-end labelling assay

DNA fragmentation was assessed using the In Situ Cell Death Detection Kit (Fluorescein) according to the manufacturer's instructions. Briefly, cells $\left(8 \times 10^{5}\right)$ were incubated with test compounds for $24 \mathrm{~h}$, detached with a $0.5 \%$ trypsin-EDTA solution and collected. The cell suspension was fixed with $4 \%$ paraformaldehyde and permeabilised with $0.1 \%$ sodium citrate. After the reaction mixture was added, cells were incubated for $30 \mathrm{~min}$ and samples were analysed by flow cytometry (Becton Dickinson FACScan ${ }^{\mathrm{TM}}$; Beckton Dickinson, Franklin Lakes, NJ, USA). Concentrations of test compounds correspond to the concentrations applied to the caspase- 3 assay.

\section{Statistical analysis}

All results are means from three to seven separate experiments in triplicate. Statistical analysis was performed by oneway ANOVA followed by Tukey's post hoc test. We used $P<0.05$ as the cut-off for significant difference.

\section{Results}

\section{Cytotoxicity}

To investigate the effect of sterols and their epoxy-derivatives on human abdominal aorta endothelial cells, HAAE-2 cells were treated with different concentrations of test compounds and cell growth was evaluated after 24 and $72 \mathrm{~h}$ (Fig. 2 (A)). $\beta$-Sitosterol was shown to be more cytotoxic than cholesterol in almost the whole range of concentrations in both incubation time intervals. The cytotoxic activity of $\beta$-sitosterol was revealed even in low concentrations $(0.125 \mu \mathrm{M})$ while incubation of cells with cholesterol resulted in a significant cell viability inhibition only in almost ten times higher concentration. The cytotoxicity of both test substances increased with incubation time but only in some concentration ranges. $\beta$-Sitosterol treatment resulted in cell viability inhibition by $10 \%$ in the concentration of $0.125 \mu \mathrm{M}$ after $24 \mathrm{~h}$ of incubation. The inhibitory effect was more effective at the concentration of $0.25 \mu \mathrm{M}$ and it was similar for both time intervals. At the concentration of $0.5 \mu \mathrm{M}, \quad \beta$-sitosterol showed $25 \%$ inhibition after $24 \mathrm{~h}$ and almost $50 \%$ inhibition after $72 \mathrm{~h}$ of incubation. The inhibitory effect was increased with concentration and incubation time; however, at the concentration of $2 \mu \mathrm{M}$ and higher the incubation time did not significantly change the cytotoxicity. Similarly, cholesterol inhibited cell growth in a time- and dose-dependent manner but significant changes in cell viability were observed at the concentration of $1 \mu \mathrm{M}$ and higher. Cholesterol showed higher cytotoxicity at $4 \mu \mathrm{M}$ when cells were incubated for $72 \mathrm{~h}(50 \%$ growth inhibition) compared with the effect observed at $24 \mathrm{~h}$ ( $20 \%$ growth inhibition). However, $\beta$-sitosterol was shown to be more cytotoxic than cholesterol at all concentration and incubation time ranges; both substances finally revealed $70 \%$ cytotoxicity at the concentrations of $8 \mu \mathrm{M}$ ( $\beta$-sitosterol) and $16 \mu \mathrm{M}$ (cholesterol).

To investigate the influence of sterol epoxy-derivatives, i.e. $5 \alpha, 6 \alpha$-epoxysitosterol and $5 \alpha, 6 \alpha$-epoxycholesterol, on human abdominal aorta endothelial cell (HAAE-2) growth, cells were supplemented with varying concentrations of test compounds and cell growth was evaluated after 24 and $72 \mathrm{~h}$ (Fig. 2 (B)). The analysis demonstrated that $5 \alpha, 6 \alpha$-epoxy- $\beta$-sitosterol decreased the viability of the cells by about $10-20 \%$ in the whole concentration range, while incubation time and compound concentration slightly increased this effect. It was also shown that $5 \alpha, 6 \alpha$-epoxycholesterol in the range of $2-16 \mu \mathrm{M}$ at the $24 \mathrm{~h}$ incubation time did not alter cell viability, while at the concentration of $32 \mu \mathrm{M}$ at the same time a pro-proliferative effect was observed at the level of almost $20 \%$ compared with control cells. At higher concentrations $5 \alpha, 6 \alpha$-epoxycholesterol decreased cell viability by up to $90 \%$ at the concentration of $128 \mu \mathrm{M}$. When cells were treated for $72 \mathrm{~h}$ the results were similar, showing no effect of $5 \alpha, 6 \alpha-$ epoxycholesterol in the concentration range of $2-16 \mu \mathrm{M}$; however, at the concentration of $32 \mu \mathrm{M}$ a growth-inhibitory effect was observed at the level of over $20 \%$ and that effect was increased with concentration up to $90 \%$ inhibition at $64 \mu \mathrm{M}$.

A comparison of sterols and their epoxy-derivatives revealed that oxy-sterols significantly inhibited cell growth but only in concentrations a few times higher compared with basal substances.

The study of the mixture of oxyphytosterols derived from the oil extract and their influence on cell viability at $24 \mathrm{~h}$ of incubation revealed that these compounds slightly decreased cell number in the concentration range of $2 \cdot 24-71.8 \mu \mathrm{g} / \mathrm{ml}$ by about $10 \%$ (Fig. 2 (C)). This effect was potentiated by higher concentrations, reaching $20 \%$ at the concentration of 

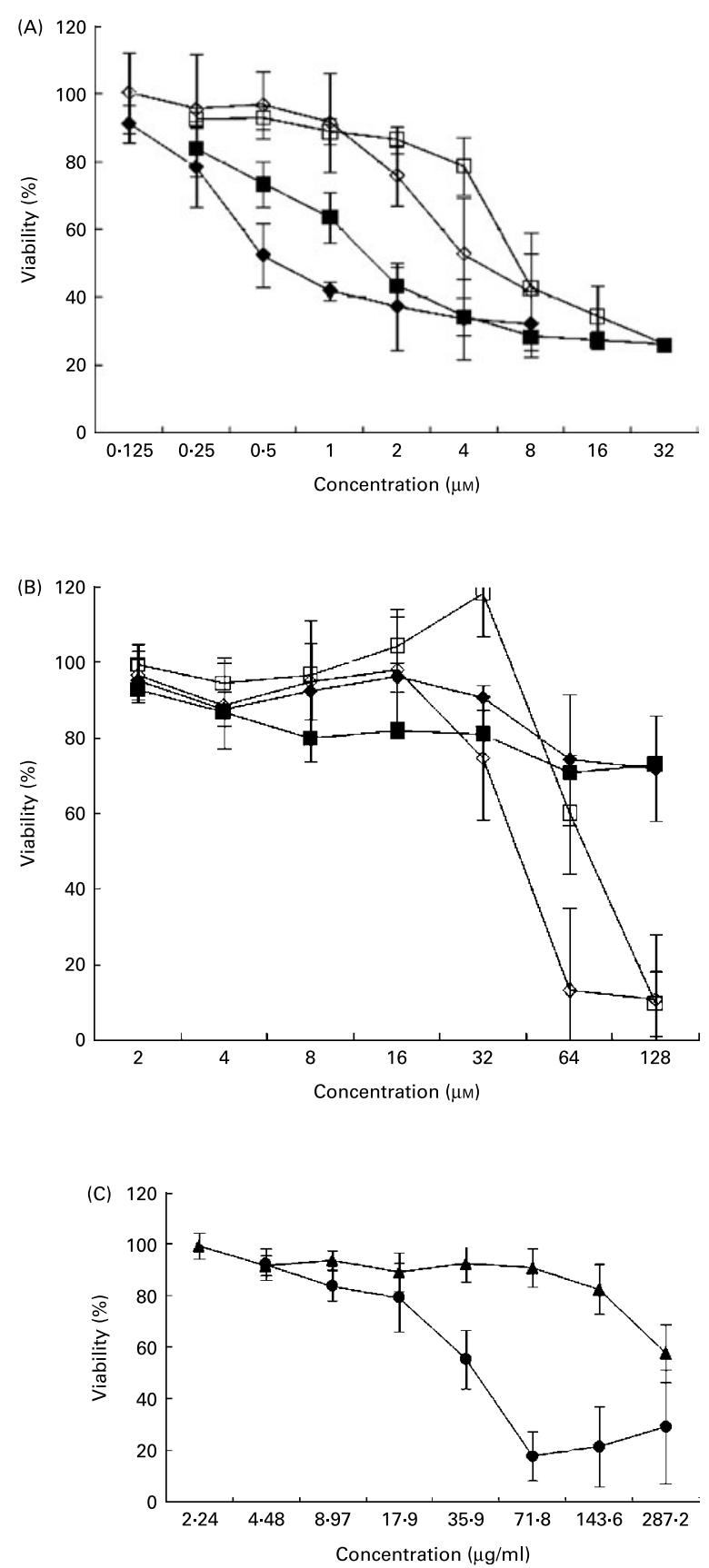

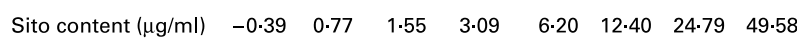

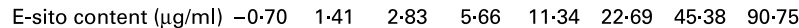

Fig. 2. Sensitivity of human abdominal aorta endothelial cells (HAAE-2) to sterols. Cytotoxicity of sterols was evaluated with the 1-(4,5-dimethylthiazol2-yl)-3,5-diphenylformazan (MTT) test after 24 and $72 \mathrm{~h}$ of incubation time. The cells were cultured in Ham's F12K medium, as specified in Materials and methods, on ninety-six-well titration plates in the presence of test substances dissolved in acetone. At time intervals, $0.5 \%$ MTT was added followed by incubation with a solubilisation solution. Absorbance intensity was read by a Labsystems Multiscan RC (Helsinki, Finland) at $\lambda=570$ and $690 \mathrm{~nm}$. Proliferation rate was expressed as the absorbance of a sample compared with control cells treated with acetone $(1 \%)$ and the half maximal inhibitory concentration $\left(\mathrm{IC}_{50}\right)$ values were calculated using CalcuSyn (BioSoft, Ferguson, MO, USA). The data are means from three to seven separate experiments in triplicate, with standard errors represented by vertical
$143.6 \mu \mathrm{g} / \mathrm{ml}$ and $40 \%$ at the concentration of $287.2 \mu \mathrm{g} / \mathrm{ml}$. When cells were treated with the oil extract for $72 \mathrm{~h}$ with concentrations of $2 \cdot 24-17.9 \mu \mathrm{g} / \mathrm{ml}$, cell viability decreased with concentration up to $20 \%$ while further concentration increase showed higher cytotoxic effect, reaching almost $50 \%$ inhibition at $35.9 \mu \mathrm{g} / \mathrm{ml}$ and $80 \%$ at the concentration of $71.8 \mu \mathrm{g} / \mathrm{ml}$ and higher.

Calculation of $\mathrm{IC}_{50}$ values enabled comparison of test substance cytotoxicity. It was revealed that after $24 \mathrm{~h}$ of incubation in the presence of $\beta$-sitosterol, $50 \%$ of cells were killed by the concentration of $1.99 \mu \mathrm{M}\left(\mathrm{IC}_{50}\right)$ compared with incubation with cholesterol when $50 \%$ of cells were killed by the concentration of $8.99 \mu \mathrm{M}$ (Table 2). Incubation time increase up to $72 \mathrm{~h}$ resulted in decreases in $\mathrm{IC}_{50}$ to 1.33 and $5.84 \mu \mathrm{M}$ respectively (Table 2). Calculation of $\mathrm{IC}_{50}$ values for sterol epoxy-derivative treatment for $24 \mathrm{~h}$ did not give results. However, incubation for $72 \mathrm{~h}$ showed significant cytotoxicity of the compounds (Table 2).

Cell viability in the presence of individual test substances was also assessed using a trypan blue assay (Table 3). Significant viability differences compared with control were observed in cells treated with $2 \mu \mathrm{M}-\beta$-sitosterol and oil extract at $147.6 \mu \mathrm{g} / \mathrm{ml}$. Other study compounds and their concentrations did not show any significant changes in cell viability.

\section{Apoptosis assessment}

Influence of sterols on caspase-3 activity. To investigate the contribution of test compounds to the mechanism of apoptosis in human abdominal aorta endothelial cells, HAAE-2, cells were treated for $24 \mathrm{~h}$ with test compounds in concentrations close to $\mathrm{IC}_{50}$ and the caspase- 3 activity assay was performed (Fig. 3 (A)). It was demonstrated that $\beta$-sitosterol significantly increased the enzyme activity by over $60 \%$ compared with control. No significant difference was shown in enzyme activity when cells were treated with epoxyderivatives of sterols while the cholesterol and oil extract slightly increased the caspase- 3 activity by about 15 and $25 \%$, respectively.

Influence of sterols on DNA fragmentation. In order to estimate the contribution of test compounds to the final step of apoptosis, human abdominal aorta endothelial cells, HAAE-2, were treated with concentrations of test compounds close to $\mathrm{IC}_{50}$ for $24 \mathrm{~h}$ and a DNA fragmentation assay (TUNEL) was performed (Fig. 3 (B)). The effect of $\beta$-sitosterol was over two times higher compared with control while the relative TUNEL positive cells in the samples treated with cholesterol, $\alpha$-epoxycholesterol and oil extract were almost three times higher compared with control. No DNA fragmentation increase was observed in cells treated for $24 \mathrm{~h}$ with $\alpha$-epoxysitosterol.

bars. (A) $\beta$-Sitosterol at $24 \mathrm{~h}$ incubation time ( $\square), \beta$-sitosterol at $72 \mathrm{~h}$ incubation time $(\bullet)$, cholesterol at $24 \mathrm{~h}$ incubation time $(\square)$, cholesterol at $72 \mathrm{~h}$ incubation time $(\diamond)$. (B) $5 \alpha, 6 \alpha$-Epoxy- $\beta$-sitosterol at $24 \mathrm{~h}$ incubation time $(\boldsymbol{\square})$ $5 \alpha, 6 \alpha$-epoxy- $\beta$-sitosterol at $72 \mathrm{~h}$ incubation time $(\bullet), 5 \alpha, 6 \alpha$-epoxycholesterol at $24 \mathrm{~h}$ incubation time $(\square), 5 \alpha, 6 \alpha$-epoxycholesterol at $72 \mathrm{~h}$ incubation time $(\diamond)$. (C) Oil extract at $24 \mathrm{~h}$ incubation $(\Delta)$ and $72 \mathrm{~h}$ incubation $(\bullet)$. Standardised values of $\beta$-sitosterol (Sito) and $5 \alpha, 6 \alpha$-epoxysitosterol (E-sito) content in oil extract are given. 
Table 2. Half maximal inhibitory concentration $\left(\mathrm{IC}_{50}\right)$ values* (Mean values with their standard errors of three experiments in triplicate)

\begin{tabular}{|c|c|c|c|c|}
\hline \multirow{2}{*}{$\begin{array}{l}\text { Incubation time... } \\
\text { Compound }\end{array}$} & \multicolumn{2}{|c|}{$24 \mathrm{~h}$} & \multicolumn{2}{|c|}{$72 \mathrm{~h}$} \\
\hline & Mean & SEM & Mean & SEM \\
\hline$\beta$-Sitosterol $(\mu \mathrm{M})$ & 1.99 & 0.56 & 1.33 & 0.38 \\
\hline Cholesterol & 8.99 & 2.74 & $5 \cdot 84$ & 1.98 \\
\hline $5 \alpha, 6 \alpha$-Epoxysitosterol $(\mu \mathrm{M})$ & \multicolumn{2}{|c|}{$>200$} & 177.55 & $15 \cdot 34$ \\
\hline $5 \alpha, 6 \alpha-$ Epoxycholesterol $(\mu \mathrm{M})$ & \multicolumn{2}{|c|}{$>200$} & $45 \cdot 74$ & 7.62 \\
\hline Oil extract $(\mu \mathrm{g} / \mathrm{ml})$ & \multicolumn{2}{|c|}{$>300$} & 42.49 & 6.92 \\
\hline$\beta$-Sitosterol content $(\mu \mathrm{M})$ & \multicolumn{2}{|c|}{$>51.79$} & \multicolumn{2}{|c|}{ 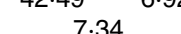 } \\
\hline $5 \alpha, 6 \alpha-$ Epoxysitosterol content $(\mu \mathrm{M})$ & \multicolumn{2}{|c|}{$>94.79$} & \multicolumn{2}{|c|}{13.42} \\
\hline
\end{tabular}

* The values of $\mathrm{IC}_{50}$ were calculated using CalcuSyn (BioSoft, Ferguson, MO, USA) and are expressed in $\mu \mathrm{m}$ or $\mu \mathrm{g} / \mathrm{ml}$.

\section{Discussion}

Within the last few years much information has been discovered and published concerning the biological activity of phytosterols. They have been studied in the context of antiproliferative action on cancer cells ${ }^{(3)}$ as well as protection for normal cells ${ }^{(14)}$. However, the data concerning advantages or disadvantages of phytosterol uptake are very diverse. The in vitro studies revealed that $\beta$-sitosterol is a strong antiproliferative agent in breast cancer cells T-47D, while an adverse effect was observed in other breast cancer cells, MCF-7, treated with $1 \mu \mathrm{M}$ concentration of this compound ${ }^{(15)}$. This was also confirmed by other researchers showing a pro-proliferative action of $\beta$-sitosterol on MCF-7 cells at concentrations of $0.001-150 \mu \mathrm{M}^{(16)}$. Consequently its oestrogenic potency was suggested. Noteworthy, no effect of $\beta$-sitosterol was shown on the expression of $\mathrm{Bcl}-2$ and $P s 2$ genes, which are engaged in cell-cycle control. On the contrary, it was shown that $\beta$-sitosterol was cytotoxic in Caco-2, HepG2 and MCF-7 (IC 50 values $20,53,71 \cdot 2 \mu \mathrm{M}$, respectively) ${ }^{(17)}$.

It is also suggested that $\beta$-sitosterol might play an important role in cancer prevention and therapy, which was shown in vitro in HCT116 colon cancer cells. Their viability was inhibited by $\beta$-sitosterol by about $50 \%$ at the concentration of $7.5 \mu \mathrm{M}^{(3)}$. It was also demonstrated that $\beta$-sitosterol induced caspase- 3 and caspase- 9 activity and that this effect was accompanied by a proteolytic cut of poly(ADP-ribose)

Table 3. Trypan blue cell viability assay

(Mean values with their standard errors of three experiments in triplicate)

\begin{tabular}{lcr}
\hline & \multicolumn{2}{c}{ Cell death number (\%) } \\
\cline { 2 - 3 } Substances & Mean & SEM \\
\hline Control & 11.5 & $4 \cdot 6$ \\
Acetone, $1 \%$ & 11.7 & $4 \cdot 2$ \\
$\beta$-Sitosterol, $0.5 \mu \mathrm{M}$ & $14 \cdot 3$ & 4.0 \\
$\beta$-Sitosterol, $2 \mu \mathrm{M}$ & $22 \cdot 6$ & $2 \cdot 3$ \\
$\alpha$-Epoxysitosterol, $2 \mu \mathrm{M}$ & $14 \cdot 8$ & $0 \cdot 8$ \\
$\alpha$-Epoxysitosterol, $128 \mu \mathrm{M}$ & $14 \cdot 6$ & 1.5 \\
Oil extract, $71.8 \mu \mathrm{g} / \mathrm{ml}$ & 16.3 & 3.5 \\
Oil extract, $147.6 \mu \mathrm{g} / \mathrm{ml}$ & 45.8 & 14.6 \\
Oil extract, $287 \mu \mathrm{g} / \mathrm{ml}$ & 88.0 & $5 \cdot 3$ \\
\hline
\end{tabular}

polymerase. It was also shown that during the apoptosis resulting from $\beta$-sitosterol treatment, a decrease in mRNA specific for anti-apoptotic protein $\mathrm{Bcl}-2$ and $\mathrm{Bcl}-2$ protein itself with simultaneous increase in mRNA of pro-apoptotic protein
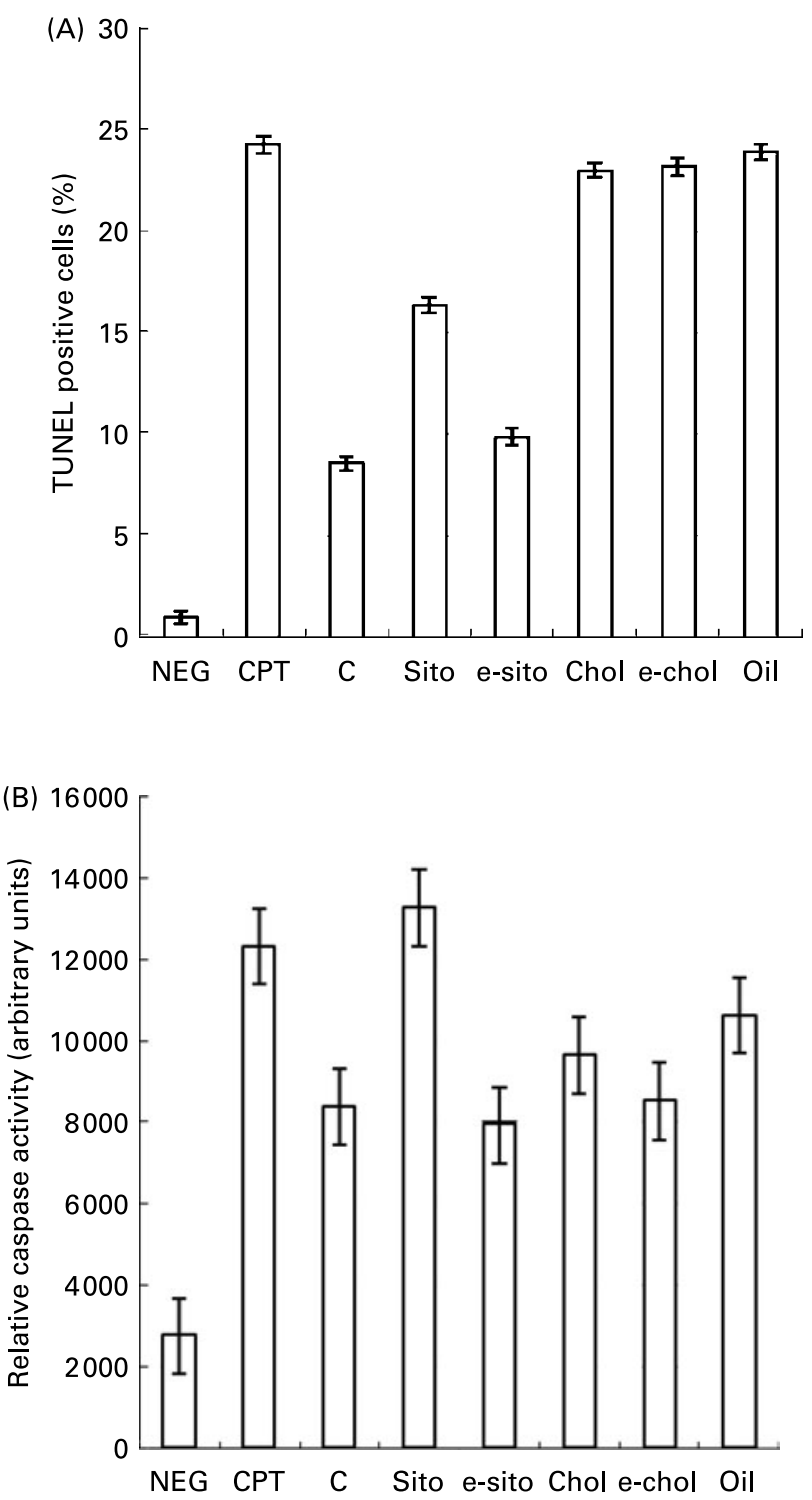

Fig. 3. Apoptosis in endothelial cells provoked by sterols. HAAE-2 cells $\left(8 \times 10^{5}\right)$ were treated for $24 \mathrm{~h}$ with test compounds in concentrations close to half maximal inhibitory concentration $\left(\mathrm{IC}_{50}\right)$ and both the caspase- 3 activity assay and the terminal uridine deoxynucleotidyl transferase-mediated deoxyuridine triphosphate nick-end labelling (TUNEL) assay were performed. The caspase activity was assessed with an ELISA test at $\lambda=496 / 520 \mathrm{~nm}$ and DNA fragmentation was evaluated using an In Situ Cell Death Detection Kit by flow cytometry (FACScan ${ }^{\text {TM}}$; Beckton Dickinson, Franklin Lakes, NJ, USA). The data are means from three separate experiments, with standard errors represented by vertical bars. (A) Caspase- 3 activity in HAAE-2 cells in the presence of test substances: NEG, negative control (MCF-7 cells, showing no caspase-3 activity); CPT, camptothecin (2.5 $\mu \mathrm{M})$; C, control untreated cells; sito, $\beta$-sitosterol $(0.5 \mu \mathrm{M})$; e-sito, $5 \alpha, 6 \alpha$-epoxy- $\beta$-sitosterol $(2 \mu \mathrm{M})$; chol, cholesterol $(0.5 \mu \mathrm{M})$; e-chol, $5 \alpha, 6 \alpha$-epoxycholesterol $(2 \mu \mathrm{M})$; oil, oil extract $(2.9 \mu \mathrm{g} / \mathrm{ml})$. (B) DNA fragmentation in HAAE-2 cells in the presence of test substances: NEG, negative control (sample without terminal transferase); CPT, camptothecin $(2.5 \mu \mathrm{M})$; C, control untreated cells; sito, $\beta$-sitosterol $(0.5 \mu \mathrm{M})$; e-sito, $5 \alpha, 6 \alpha$-epoxy- $\beta$-sitosterol $(2 \mu \mathrm{M})$; chol, cholesterol $(0.5 \mu \mathrm{M})$; e-chol, $5 \alpha, 6 \alpha$-epoxycholesterol $(2 \mu \mathrm{M})$; oil, oil extract $(2 \cdot 9 \mu \mathrm{g} / \mathrm{ml})$. 
Bax was observed ${ }^{(3)}$. Similarly, because $\beta$-sitosterol shows a growth-inhibitory effect and has an influence on apoptosis induction in breast cancer cells MCF-7, it was suggested that it might be an important diet complement in breast cancer therapy ${ }^{(18)}$.

Simultaneously, the influence of $\beta$-sitosterol on normal cells and their function in atherosclerosis has been discussed. Awad et al. ${ }^{(19)}$ showed that this phytosterol inhibited smooth muscle cell (SMC) proliferation and, thus, inhibited plaque formation. This was shown in in vitro studies, when $16 \mu \mathrm{M}$ $\beta$-sitosterol inhibited smooth muscle cell proliferation by about $30 \%$. Since it was described as a proliferation inhibitor, $\beta$-sitosterol was not proved to have cytotoxic properties. It was described positively, because cell death is supposed to be one of the reasons for plaque formation or plaque break resulting in an increased coagulation ${ }^{(19)}$. The results of the present study reveal strong cytotoxic properties of $\beta$-sitosterol in endothelial cells. Even at the concentration of $2 \mu \mathrm{M}$, much lower than physiological (about $5 \mu \mathrm{M}$ ) serum concentration ${ }^{(20)}$, after $24 \mathrm{~h}$ incubation time $\beta$-sitosterol decreased human abdominal aorta endothelial cell (HAAE-2) viability by about $50 \%$. Noteworthy, treatment of cells with a concentration of oil extract containing a similar level of $\beta$-sitosterol demonstrated only a minor cytotoxic effect. Only the concentrations of oil containing higher concentrations of $\beta$-sitosterol $(>16 \mu \mathrm{M})$, remarkably exceeding the physiological value, resulted in a significant cell-growth inhibition $(P<0.05)$. This might indicate interactions between individual oil extract compounds. Interestingly, $5 \alpha, 6 \alpha$-epoxy- $\beta$-sitosterol in a wide range of concentrations $(2-128 \mu \mathrm{M})$ showed a weaker cytotoxic effect than its parent compound, $\beta$-sitosterol. We hypothesise that this may be due to the oxidation process that if taking place in cells in vitro can not only produce harmful epoxy forms but also generate free radicals. Otherwise, if epoxy-compounds are delivered into the cells their toxic spectrum is also very broad but deprived of an oxidation stress effect.

Anti-atherogenic effects of plant sterols may be not only due to their cholesterol-lowering activities alone, but also to other properties such as effects on the coagulation system, antioxidant system, and hepatic and lipoprotein lipase activities $^{(21)}$. Furthermore, it has been shown that high $\beta$-sitosterol levels (up to $0.7 \mathrm{mmol} / \mathrm{l}$ ) can cause contraction of human umbilical vein endothelial cells in vitro ${ }^{(22)}$. These observations suggest that very high plasma concentrations of $\beta$-sitosterol may have potentially cytotoxic effects and may interfere with cellular functions. Moreover, significantly stronger cytotoxic activity of $\beta$-sitosterol than cholesterol was observed. This might be an effect of displacing the cholesterol from the membrane and thus disturbing the membrane integrity and eliminating the natural compound.

It was also revealed that $5 \alpha, 6 \alpha$-epoxycholesterol in very low concentrations did not significantly decrease the cell viability of HAAE-2 human abdominal aorta endothelial cells, and surprisingly at the concentration of $32 \mu \mathrm{M}$ at $24 \mathrm{~h}$ incubation it induced cell proliferation comparative with control. This might be explained by the mutagenic properties of oxysterols $^{(23)}$. Only the concentrations of 64 and $128 \mu \mathrm{M}$ were remarkably cytotoxic, showing even $90 \%$ cell growth inhibition at the highest concentration. Rimner et al. ${ }^{(24)}$ showed that $5 \alpha, 6 \alpha$-epoxycholesterol was not cytotoxic for human arterial endothelial cells. It was then concluded that the role of $\alpha$ - and $\beta$-isoforms of oxysterols in the pathogenesis of CHD is different. In that study, $5 \beta, 6 \beta$-epoxycholesterol was shown to induce cell death in a concentration-dependent manner while the $5 \alpha, 6 \alpha$-derivative had a minor influence on cell death. It was also shown that $7 \beta$-hydroxycholesterol was much more cytotoxic than epoxy-derivatives. In another study Lemaire et al. ${ }^{(25)}$ observed that the position $(\alpha$ or $\beta$ ) of the hydroxyl radical plays a critical role in the induction of the apoptotic process.

In the study of O'Sullivan et al. ${ }^{(26)}$ the cholesterol derivatives were shown to be cytotoxic and induce apoptosis in bovine aorta endothelium cells and U937 cells (derived from monocytes), confirming the pro-atherogenic action of oxysterols. We showed that the oxysterol mixture could influence cell viability in a different way compared with individual mixture components, which suggests complex interactions. A study of $5 \alpha, 6 \alpha$-epoxysitosterol action was also performed by Maguire et al. ${ }^{(27)}$. It was shown that this compound may be cytotoxic for U937 cells. It was also revealed that $5 \alpha, 6 \alpha$-epoxysitosterol could inhibit macrophage growth at a concentration of $200 \mu \mathrm{g} / \mathrm{ml}$ for $120 \mathrm{~h}^{(28)}$.

In the present study, in a comparison of results received using two methods, assessing cell viability in the presence of test substances, trypan blue and MTT, significant differences were noticed. It was shown that the same substances were more cytotoxic when analysed by the MTT test than in the trypan blue assay. Thus, we may suggest that the study compounds more efficiently target cell metabolism, including cytochrome activity, than their membrane integrity. It is then supposed that $\beta$-sitosterol treatment $\left(\mathrm{IC}_{50}=2 \mu \mathrm{M}\right.$ in the MTT assay) might result in an oxidation chain block and cell death, rather than in cell membrane integrity (viability decreased only by about $10 \%$ at the concentration of $2 \mu \mathrm{M})$. It was also observed in the trypan blue assay that when cells were treated with the oil extract almost $90 \%$ of cells died, while in the MTT assay the viability of cells was decreased only by about $40 \%$ in the $24 \mathrm{~h}$ incubation time at a concentration of $143.6 \mu \mathrm{g} / \mathrm{ml}$ corresponding to $\beta$-sitosterol and epoxy- $\beta$-sitosterol contents of 24.79 and $45.38 \mu \mathrm{M}$ respectively. This might suggest that the oxyphytosterol extract influences not only the metabolism of the cells but also their membrane integrity. Thus we conclude that the action of phytosterols and their oxy-derivatives may differ. However, the MTT test enables only primary verification of individual compounds when considering their antiproliferative properties and/or influence on cell viability. But surprisingly for us, on the contrary to other studies and reports, phytosterols significantly decreased normal human endothelial (HAAE-2) cell viability. Additionally, since the MTT cell proliferation assay is a colorimetric assay system which measures the reduction of a tetrazolium component (MTT) into an insoluble formazan product by variable cell enzymes (including also mitochondrial) it can really tell what is the metabolic condition, endocytosis ability and viability or proliferation index of the cells studied. However, we realise that such results can only indicate cell growth inhibition and not apoptosis directly. Thus, further studies were performed, concerning precise description of the study compound effects, i.e. caspases and TUNEL assays. 
It is postulated that endothelial cell apoptosis may directly affect the growth of neighbouring cells, including the SMC of vessels ${ }^{(4)}$. This could result from the mechanism of releasing factors such as NO and PG that limit cell proliferation. Since apoptosis decreases the number of endothelial cells, their influence is decreased and SMC may overproliferate ${ }^{(4)}$. Apoptosis reduces the number of endothelial cells, and may result in blood-muscle cell barrier damage which leads to SMC exposure to risk factors, promoting cell growth. Moreover, apoptotic cells may contribute to increased blood coagulation, which can induce proliferation of SMC. Interestingly, it was also demonstrated that endothelial cell apoptosis causes proliferation of neighbouring SMC inducing a signal to supplement the damaged cell layer ${ }^{(29)}$. This process might be inhibited by serum $\beta$-sitosterol, which was shown to limit SMC proliferation rate ${ }^{(4)}$.

In the present study it was shown that $\beta$-sitosterol as well as cholesterol caused apoptosis, inducing caspase- 3 activity in the cells studied $(60 \%$ increase compared with control cells). The observed differences in caspase- 3 activation and DNA fragmentation that allows discrimination of apoptosis from necrosis might result from distinct reaction kinetics of both processes ${ }^{(30)}$. The present results are consistent with other studies where the pro-apoptotic effect of $\beta$-sitosterol in LNCaP cells ${ }^{(31)}$, MDA-MB-231 cells ${ }^{(5)}$ and HCT116 cells ${ }^{(3)}$ was revealed, showing caspase- 3 as well as DNA-fragmentation increase. However, this compound seems to be not selective only to cancer cells.

On the other hand, Z-DEVD-R110 is a substrate for caspases 3, 6, 7, 8 and 10; however, caspases 3, 6 and 7 predominantly cleave the substrate. Thus, we also analysed the influence of study compounds on the activity of other caspases in MCF-7 cells, showing no activity of caspase-3, and we showed no increase in the activity of any of these caspases in MCF-7 cells (negative control). Additionally we did not observe apoptosis when analysing the influence of phytosterols on MCF-7 cells in cytometric analysis. We realise that this information can be deceptive, because these two cell types can differ strikingly in other metabolic pathways, not only in caspase- 3 activity. Anyway, when analysing the properties of the phytosterols studied, we can conclude that they probably do not provoke an increase in activity of any caspases other than caspase-3.

So far, a protective influence of phytosterols on the human organism and atherosclerosis has been suggested. The proposed mechanism of this action was connected with decreased LDL capacity of cholesterol as a result of decreased intestine absorption which might be caused by $\beta$-sitosterol ${ }^{(32)}$. It seems that in atherosclerosis prevention one of the most important factors is keeping a balance in proliferation and apoptosis of endothelial cells as it happens in $\mathrm{SMC}^{(32)}$. $\beta$-Sitosterol, inhibiting endothelial cell growth, might cause a break in the inner vessel wall and thus the apoptotic signals could induce the neighbouring cells to proliferate including over-proliferation of SMC, without the death of cells ${ }^{(29)}$.

On the other hand, $\beta$-sitosterol has been shown to inhibit proliferation of $\mathrm{SMC}^{(4)}$ which might probably attenuate its influence on blood vessel condition. Since $\beta$-sitosterol is supplied to our body together with food as one of its compounds, it is very difficult to appreciate its role and activity because of the presence of multiple vitamins, antioxidants and other compounds that can modulate the effect of its own. This is consistent with the studies of sunflower-seed oil containing $48.7 \%$ of $\beta$-sitosterol; there were no changes in the blood vessels of rats fed with the oil for $90 \mathrm{~d}^{(33)}$. We observed that $\beta$-sitosterol decreased cell viability at the concentrations of 0.25 and $0.5 \mu \mathrm{M}$ while treatment of cells with the oil extract corresponding to the same $\beta$-sitosterol concentration (1.42 and $2.84 \mu \mathrm{M}$, respectively) did not show any significant effect. An opposite effect was observed in studies of the influence of epoxy- $\beta$-sitosterol alone when it decreased cell viability much more effectively if added in an oil extract.

It is then concluded that further studies on phytosterols, including those after thermal processing, and their influence on vessels in vivo is required, especially since it has been revealed that animal-derived sterols as well as phytosterols decrease cell viability in a time- and dose-dependent manner in vitro. There may be a hypothesis that phytosterols undergoing oxidation in our cells can be more dangerous that sterols already metabolised and delivered to our body in that state. This may result from the side effects of oxidation, for example, reactive oxygen species production; however, this hypothesis requires further study.

\section{Acknowledgements}

This research was financially supported by a grant from the State Committee for Scientific Research PBZ-KBN-094/P06/ 2003.

There are no financial or other contractual agreements that might cause conflicts of interest or be perceived as causing conflicts of interest. There are no potential conflicts of interest. There is no financial arrangement between any of the authors and any company whose product figures in the paper. All authors read and approved the final submitted manuscript.

\section{References}

1. Awad AB, Roy R \& Fink CS (2003) $\beta$-Sitosterol, a plant sterol, induces apoptosis and activates key caspases in MDA-MB-231 human breast cancer cells. Oncol Rep 10, 497-500.

2. Tapiero H, Townsend DM \& Tew KD (2003) Phytosterols in the prevention of human pathologies. Biomed Pharmacother 57, $321-325$.

3. Choi YH, Kong KR, Kim YA, Jung KO, Kil JH, Rhee SH \& Park KY (2003) Induction of Bax and activation of caspases during $\beta$-sitosterol-mediated apoptosis in human colon cancer cells. Int J Oncol 23, 1657-1662.

4. Awad AB, Smith AJ \& Fink CS (2001) Plant sterols regulate rat vascular smooth muscle cell growth and prostacyclin release in culture. Prostaglandins Leukot Essent Fatty Acids 64, 323-330.

5. Awad AB \& Fink CS (2000) Phytosterols as anticancer dietary components: evidence and mechanism of action. J Nutr 130, 2127-2130.

6. de Jong A, Plat J \& Mensink RP (2003) Metabolic effects of plant sterols and stanols (review). J Nutr Biochem 14, 362-369.

7. Ronco A, De Stefani E, Boffetta P, Deneo-Pellegrini H, Mendilaharsu M \& Leborgne F (1999) Vegetables, fruits, and related nutrients and risk of breast cancer: a case-control study in Uruguay. Nutr Cancer 35, 111-119.

8. Awad AB, Burr AT \& Fink CS (2005) Effect of resveratrol and $\beta$-sitosterol in combination on reactive oxygen species 
and prostaglandin release by PC-3 cells. Prostaglandins Leukot Essent Fatty Acids 72, 219-226.

9. Salen G, Horak I, Rothkopf M, Cohen JL, Speck J, Tint GS, Shore V, Dayal B, Chen T \& Shefer S (1985) Lethal atherosclerosis associated with abnormal plasma and tissue sterol composition in sitosterolemia with xanthomatosis. J Lipid Res 26, 1126-1133.

10. Fieser M \& Fieser LF (1967) Reagents for Organic Synthesis, vol. 1, pp. 136-137. New York: Wiley.

11. Rudzińska M, Jeleń H \& Węsowicz E (2002) The content of phytosterols and their oxidized derivatives in heated plant oils. Pol J Food Nutr Sci 11/52, Suppl. 1, 129-134.

12. Rudzińska M, Kazuś T \& Węsowicz E (2001) Sterols and their oxidized derivatives in refined and cold pressed seed oils. Rośl Oleiste 22, 477-494.

13. Carmichael J, DeGraff WG, Gazdar AF, Minna JD \& Mitchell JB (1987) Evaluation of a tetrazolium-based semiautomated colorimetric assay: assessment of chemosensitivity testing. Cancer Res 47, 936-942.

14. Awad AB, Williams H \& Fink CS (2003) Effect of phytosterols on cholesterol metabolism and MAP kinase in MDA-MB-231 human breast cancer cells. J Nutr Biochem 14, 111-119.

15. Mellanen $P$, Petänen $T$, Lehtimäki J, Mäkelä S, Bylund G, Holmbom B, Mannila E, Oikari A \& Santti R (1996) Woodderived estrogens: studies in vitro with breast cancer cell lines and in vivo in trout. Toxicol Appl Pharmacol 136, 381-388.

16. Ju YH, Clausen LM, Allred KF, Almada AL \& Helferich WG (2004) $\beta$-Sitosterol, $\beta$-sitosterol glucoside, and a mixture of $\beta$-sitosterol and $\beta$-sitosterol glucoside modulate the growth of estrogen-responsive breast cancer cells in vitro and in ovariectomized athymic mice. $J$ Nutr 134, 1145-1151.

17. Rahmat A, Kumar V, Fong LM, Endrini S \& Sani HA (2004) Determination of total antioxidant activity in three types of local vegetables shoots and the cytotoxic effect of their ethanolic extracts against different cancer cell lines. Asia Pac J Clin Nutr 13, 308-311.

18. Awad AB, Chinnam M, Fink CS \& Bradford PG (2007) $\beta$-Sitosterol activates Fas signaling in human breast cancer cells. Phytomedicine 14, 747-754.

19. Awad AB, Williams H \& Fink CS (2001) Phytosterols reduce in vitro metastatic ability of MDA-MB-231 human breast cancer cells. Nutr Cancer 40, 157-164.

20. Moghadasian MH, McManus BM, Godin DV, Rodrigues B \& Frohlich JJ (1999) Proatherogenic and antiatherogenic effects of probucol and phytosterols in apolipoprotein E-deficient mice: possible mechanisms of action. Circulation 99, 1733-1739.
21. Boberg KM, Pettersen KS \& Prydz H (1991) Toxicity of sitosterol to human umbilical vein endothelial cells in vitro. Scand J Clin Lab Invest 51, 509-516.

22. Pinedo S, Vissers MN, von Bergmann K, Elharchaoui K, Lütjohann D, Luben R, Wareham NJ, Kastelein JJ, Khaw KT \& Boekholdt SM (2007) Plasma levels of plant sterols and the risk of coronary artery disease: the prospective EPIC-Norfolk Population Study. J Lipid Res 48, 139-144.

23. Guardiola F, Codony R, Addis PB, Rafecas M \& Boatella J (1996) Biological effects of oxysterols: current status. Food Chem Toxicol 34, 193-211.

24. Rimner A, Al Makdessi S, Sweidan H, Wischhusen J, Rabenstein B, Shatat K, Mayer P \& Spyridopoulos I (2005) Relevance and mechanism of oxysterol stereospecifity in coronary artery disease. Free Radic Biol Med 38, 535-544.

25. Lemaire S, Lizard G, Monier S, Miguet C, Gueldry S, Volot F, Gambert P \& Néel D (1998) Different patterns of IL-1 secretion, adhesion molecule expression and apoptosis induction in human endothelial cells treated with $7 \alpha-, 7 \beta$-hydroxycholesterol, or 7-ketocholesterol. FEBS Lett 440, 434-439.

26. O'Sullivan AJ, O'Callaghan YC \& O'Brien NM (2005) Differential effects of mixtures of cholesterol oxidation products on bovine aortic endothelial cells and human monocytic U937 cells. Int J Toxicol 24, 173-179.

27. Maguire L, Konoplyannikov M, Ford A, Maguire AR \& O'Brien NM (2003) Comparison of the cytotoxic effects of $\beta$-sitosterol oxides and a cholesterol oxide, $7 \beta$-hydroxycholesterol, in cultured mammalian cells. Br J Nutr 90, 767-775.

28. Adcox C, Boyd L, Oehrl L, Allen J \& Fenner G (2001) Comparative effects of phytosterol oxides and cholesterol oxides in cultured macrophage-derived cell lines. J Agric Food Chem 49, 2090-2095.

29. Qin C \& Liu Z (2007) In atherogenesis, the apoptosis of endothelial cell itself could directly induce over-proliferation of smooth muscle cells. Med Hypotheses 68, 275-277.

30. Brecht S, Gelderblom M, Srinivasan A, Mielke K, Dityateva G \& Herdegen T (2001) Caspase-3 activation and DNA fragmentation in primary hippocampal neurons following glutamate excitotoxicity. Brain Res Mol Brain Res 94, 25-34.

31. von Holtz RL, Fink CS \& Awad AB (1998) $\beta$-Sitosterol activates the sphingomyelin cycle and induces apoptosis in LNCaP human prostate cancer cells. Nutr Cancer 32, 8-12.

32. Mayr M \& Xu Q (2001) Smooth muscle cell apoptosis in arteriosclerosis. Exp Gerontol 36, 969-987.

33. Hepburn PA, Horner SA \& Smith M (1999) Safety evaluation of phytosterol esters. Part 2 . Subchronic 90 -day oral toxicity study on phytosterol esters - a novel functional food. Food Chem Toxicol 37, 521-532. 